\title{
DESIGN, DEVELOPMENT AND EVALUATION OF MOUTH DISSOLVING TABLETS OF TOFACITINIB CITRATE
}

\author{
MEGHANA RAYKAR ${ }^{1}$, MALARKODI VELRAJ ${ }^{2 *}$ \\ 1,2Department of Pharmaceutical Sciences, School of Pharmaceutical Sciences, Vels Institute of Science, Technology and Advanced Studies, \\ Chennai, Tamil Nadu, India, Chennai, Tamilnadu, India \\ Email: malarkodisanna@gmail.com \\ Received: 01 Aug 2021, Revised and Accepted: 13 Oct 2021
}

\section{ABSTRACT}

Objective: This study aims to Formulate Mouth Dissolving Tablets (MDTs) of Tofacitinib Citrate with the increase in bioavailability and patient compliance.

Methods: Mouth Dissolving Tablets (MDTs) of Tofacitinib Citrate were developed by full factorial design at $3^{2}$ levelsand prepared by direct compression method using super integrants like sodium starch glycolate, Ludiflash. The tablets were compressed into compacts on a 10 station tablet machine. The bulk drug was characterised by determining, MP, Solubility, pH and FTIR spectra.

Results: The weight variation, hardness and diameter, thickness, friability, drug content, wetting time, in vitro disintegration time and in vitro dissolution studies, and stability study, tablet thickness, weight variation and drug content post compression parameters remained consistent and reproducible. All the formulations showed, almost 100 percent of drug release within 75 min. Formulations F1, F2 and F3 were prepared with $5 \mathrm{mg}$ of SSG and $20 \mathrm{mg}, 30 \mathrm{mg}$, and $40 \mathrm{mg}$ Ludiflash which shows \% release of drug in the order of F1<F2<F3. Formulations F4, F5 and F6 were prepared with $10 \mathrm{mg}$ of SSG and $20 \mathrm{mg}, 30 \mathrm{mg}$, and $40 \mathrm{mg}$ Ludiflash which shows \% release of drug in the order of F4<F5<F6. Formulations F7, F8 and F9 were prepared with $15 \mathrm{mg}$ of SSG and $20 \mathrm{mg}, 30 \mathrm{mg}$, and $40 \mathrm{mg}$ Ludiflash which shows \% release of drug in the order of F7<F8<F9.

Conclusion: It is concluded that the amount of superdisintegrants decreases disintegration time of tablets, decreases wetting time, increases the cumulative \% drug release causes better absorption.

Keywords: Mouth dissolving tablets (MDTs), Tofacitinib citrate, Sodium starch glycolate (SSG), Ludiflash, Factorial design, Bioavailability and bioequivalence (BABE)

(C) 2022 The Authors. Published by Innovare Academic Sciences Pvt Ltd. This is an open access article under the CC BY license (https://creativecommons.org/licenses/by/4.0/) DOI: https://dx.doi.org/10.22159/ijap.2022v14i1.42810. Journal homepage: https://innovareacademics.in/journals/index.php/ijap

\section{INTRODUCTION}

Mouth Dissolving Tablets (MDTs) dissolve or disintegrate in saliva and are swallowed without the need of water. MDTs offer an advantage over the conventional tablets because of their convenience of easy manufacturing, self-administration, Compactness. Therefore it improves the onset of action, increases bioavailability, and stability which helps to improve the choice of the dosage form in the current market [1,2]. It also applies to people who are ill in bed, in traveling, and also those who are busy, especially those who have no access to water dissolves in the oral cavity within 15-3 min [3]. The demand for the development of Mouth Dissolving Tablets (MDTs) has hugely increased as it has better compliance in patients [4]. Mouth Dissolving Tablets are appreciated by a significant sector of populations, particularly those who have difficulty to swallowing. It has been reported that dysphasia (difficulty in swallowing) is common for all age groups and more specific with pediatric, geriatric populations along with institutionalized patients, psychiatric patients, and patients with nausea, vomiting, and motion sickness complications [5]. MDTs with good taste and flavor increase the acceptability of bitter drugs by various groups of the population $[4,5]$. The ability to change the disease progress, cost-effectiveness, drug safety should be essential factors for all the treatments, and all these factors can be fulfilled by Mouth dissolving Tablets [6, 7]. Tofacitinib citrate is a Janus kinase JAK1/JAK3 inhibitor class [8]. It is currently developed by Pfizer for treating severe active rheumatoid arthritis in adult patients [9]. It is used for the treatment of severe active rheumatoid arthritis in adult patients, Ulcerative colitis, Psoriatic arthritis [10]. Janus kinases (JAKs) comprise a family of four enzymes, JAK1, JAK2, JAK3, and tyrosine kinase 2 (TYK2), which are centrally working in cell signaling processes important in cancer and immune-inflammatory diseases. Progression in the Pharmaceutical field has taken a recent step forward with the approval of Tofacitinib [11]. Tofacitinib citrate is a citrate salt obtained by combining equimolar amounts of tofacitinib and citric acid. Tofacitinib act as a non-specific proteintyrosine kinase inhibitor and an antirheumatic drug [12]. Also used to treat Atopic dermatitis, solid organ malignancy, and lymphoma in rheumatoid arthritis patients. The aim of this study to prepare mouth dissolving tablets of Tofacitinib Citrate used to treat certain types of arthritis [13].

\section{MATERIALS AND METHODS}

\section{Material}

Tofacitinib citrate gift sample was obtained from Formulation Development and Research Centre of Excellence, Unichem Laboratories Ltd., Goa-4035011, India. Sodium Starch Glycolate (SSG), Magnesium Stearate, Talc, Lactose was purchased from Mumbai, India [14]. The Tofacitinib citrate (Chemical Formula: C22H28N608) has 74\% oral absorption produces absolute bioavailability, with peak plasma concentration (T max) achieved in 0.5-1 hour. The volume of distribution $(\mathrm{Vd})=87 \mathrm{~L}$ after intravenous administration and has $40 \%$ protein binding, mostly bound to albumin. Distribution is equal between red blood cells and plasma half-life $\sim 3 \mathrm{~h}[15,16]$.

\section{Preparation of ludiflash}

Ludiflash is a simple mixture of $90 \% \mathrm{w} / \mathrm{w}$ of Mannitol, $5 \% \mathrm{w} / \mathrm{w}$ of Crospovidone, and $5 \% \mathrm{w} / \mathrm{w}$ of polyvinyl acetate was blended in a double cone blender and was kept in an oven for $2 \mathrm{~h}$ drying. Active pharmaceutical ingredients lubricant and other ingredients were added in the above Ludiflash excipients which Produce high Porosity tablets and having quick penetration Power [17].

\section{Method (Direct compression)}

In this process, all ingredients were accurately weighed and passed through Sieve No.180 then mixed to form powder blend and then compressed using $6 \mathrm{~mm}$ flat punch on Tablet press 10 station 
compression machine. The hardness of the tablets was maintained at $2-3 \mathrm{Kg} / \mathrm{cm} 2$. Tablet weight was maintained at $75 \mathrm{mg}[18,19]$.

\section{Characterization of tofacitinib citrate}

\section{Determination of $\lambda \max$}

For assurance of $\lambda \max$ stock solution Tofacitinib Citrate (conc. $1000 \mu \mathrm{g} / \mathrm{ml}$ ) in $0.1 \mathrm{~N} \mathrm{HCl}$ were prepared. $1 \mathrm{ml}$ of the stock arrangement was additionally weakened to $100 \mathrm{ml}$. Coming about arrangements were examined in the range of 400 to $200 \mathrm{~nm}$ utilizing methanol as a clear with the assistance of a UV-visible spectrophotometer [20]. Normal triplicate readings were taken.

Calibration curve of tofacitinib citrate in ph 6.8 phosphate buffer

A stock solution of Tofacitinib Citrate was prepared by dissolving $100 \mathrm{mg}$ of Tofacitinib Citrate in $100 \mathrm{ml}$ of phosphate buffer $\mathrm{pH}$ 6.8, to obtain $1 \mathrm{mg} / \mathrm{ml}$ solution and from which $1 \mathrm{ml}$ was withdrawn and diluted up to $100 \mathrm{ml}$ with $\mathrm{pH} 6.8$ Phosphate buffer to produce 10 $\mathrm{ug} / \mathrm{ml}$ of solution. $10 \mathrm{ug} / \mathrm{ml}$ solution was scanned for wavelength at which maximum absorbance occurs $\lambda \max$ in a U. V. Spectrophotometer (Jasco V-630, Japan) between 200-400 nm. The $\lambda \max$ was found at $287 \mathrm{~nm}$ for Tofacitinib Citrate solution in phosphate buffer $\mathrm{pH} 6.8$ and the same study was carried out in $0.1 \mathrm{~N}$ $\mathrm{HCl}$, which shows maximum absorbance at $287 \mathrm{~nm}$. Normal triplicate readings were taken [21].

\section{The partition coefficient of the drug}

Log P [22], was estimated utilizing a separating funnel by shaking equivalent volumes of oil and watery stage.

\section{Melting point identification}

The Melting purpose of Tofacitinib Citrate was resolved to utilize the open capillary technique [23].

\section{Formulation of a mouth dissolving tablet}

The mouth dissolving tablets of Tofacitinib Citrate was prepared by using $3^{2}$ full factorial design [24, 25].

Table 1: Formulae of tofacitinib citrate orally disintegrating tablets

\begin{tabular}{|c|c|c|c|c|c|c|c|c|c|c|}
\hline S. No. & Ingredients (mg) & F1 & F2 & F3 & F4 & F5 & F6 & F7 & F8 & F9 \\
\hline 1. & Tofacitinib Citrate & 5 & 5 & 5 & 5 & 5 & 5 & 5 & 5 & 5 \\
\hline 2. & Sodium Starch Glycolate & 5 & 5 & 5 & 10 & 10 & 10 & 15 & 15 & 15 \\
\hline 3. & Ludiflash & 20 & 30 & 40 & 20 & 30 & 40 & 20 & 30 & 40 \\
\hline 4. & Mag. Stearate & 1 & 1 & 1 & 1 & 1 & 1 & 1 & 1 & 1 \\
\hline 5. & Talc & 1.5 & 1.5 & 1.5 & 1.5 & 1.5 & 1.5 & 1.5 & 1.5 & 1.5 \\
\hline 6. & Lactose & q. $s$. & q. s. & q. $s$ & q. s. & q. s. & q. s. & q. s. & q. s. & q. s. \\
\hline
\end{tabular}

\section{Pre-compression parameters of a powder blend}

\section{Evaluation of pre-compression parameters}

\section{The angle of repose}

The frictional forces in a loose powder can be measured by the angle of repose. It is defined as the maximum angle possible between the surface of the pile of powder and the horizontal plane [26].

$$
\theta=\tan ^{-1}(\mathrm{~h} / \mathrm{r})
$$

Where $\theta$ is the angle of repose " $\mathrm{h}$ " is the height in cms, "r" is the radius in cms.

\section{Bulk density}

A Bulk density is determined by pouring pre sieved ( 180 mesh) bulk drug into a graduated cylinder via a large funnel and measuring the volume and weight. The average weight of triplicate readings was computed [26].

$$
\text { Bulk Density }=\frac{\text { Mass of powder }(M)}{\text { Bulk volume of the powder (V) }}
$$

\section{Tapped density}

It is the ratio of the mass of granules to the volume of the granules after it is expressed by gm/cc [27].

$$
\text { Tapped Density }=\frac{\text { Weight of powder }(\mathrm{W})}{\text { Tapped volume of the powder (V) }}
$$

\section{Carr's index}

Carr's Index was measured for the property of a powder to be compressed; as such, they are measured for the relative importance of inter particulate interactions. The average of Triplicate (three) readings was noted down [27].

$$
\text { Carr's index }(\%)=\frac{\text { Tapped Density }- \text { Bulk Density }}{\text { Tapped Density }} \times 100
$$

\section{Hausner's ratio}

This is the ratio of the poured density to the tapped density [28].

$$
\text { Hausner's Ratio }=\frac{\text { Tapped Density }}{\text { Bulk Density }}
$$

\section{Post-compression parameters}

\section{Evaluation of post-compression parameters}

\section{Thickness and diameter}

The thickness of individual tablets was measured with a micrometer which permits accurate measurement and provides information on the variation between tablets [29].

\section{Hardness}

Tablet hardness is also called crushing strength of a tablet. It may be due to poor flow properties of the powder, moisture content of the powder. Monsanto hardness tester was used to check the hardness of the tablets [30].

\section{Friability}

Twenty tablets from each batch were selected randomly and weighed. These tablets were subjected to friability testing using a friabilator (Roche type) for 100 revolutions (25 rpm for $4 \mathrm{~min}$.) Tablets were removed. De-dusted and weighed again. Average Triplicate readings were noted and SD was computed [31].

$$
\% \mathrm{~F}=\frac{\text { Initial Weight }- \text { Final Weight }}{\text { Initial Weight }} \times 100
$$

\section{Weight variation}

The 20 tablets were selected at random and weighed on a Digital balance Average of three weights was calculated from the total weight. The percentage deviations from the mean value were calculated [32].

$$
\text { Weight Variation }=\left[\frac{\mathrm{w} 1-\mathrm{w} 2}{\mathrm{w} 2}\right] \times 100 \%
$$

Where $w 1$ is the initial weight of the tablet

w2 is the average weight of the tablet

\section{Wetting time}

A petri dish containing $6 \mathrm{ml}$ of 6.8 phosphate buffer was used. A tissue paper folded twice was kept in the dish and a tablet was placed on it. A small quantity of amaranth red color was put on the upper surface of the tablet. The time required for the upper surface 
of the tablet to become red was noted as the wetting time of the tablet. An average of three readings was noted and Standard deviation was computed [33].

\section{Determination of drug content}

Ten tablets from each formulation were powdered. The powder equivalent to $5 \mathrm{mg}$ of Tofacitinib citrate was weighed and dissolved in acidic buffer pH 1.2 in $100 \mathrm{ml}$ standard flasks. From this, suitable dilution was prepared and the solution was analyzed at $287 \mathrm{~nm}$ using a UV double beam Spectrophotometer using phosphate buffer PH 6.8 as blank [34].

\section{Disintegration test}

One Tablet was placed in each of the 6 tubes of the disintegration tablet, and a disk was placed upon each tablet. The apparatus was maintained at $\left(37 \pm 0.5^{\circ} \mathrm{C}\right)$ using PH 6.8 (stimulated saliva fluid) and was operated (30 cycles/min.) The time taken for complete disintegration with no palpable mass remaining was noted. Average disintegration time and standard deviation were computed [35].

\section{Dissolution test}

In-vitro dissolution tests for all the formulations from F1-F9 were carried out by using modified dissolution apparatus [36, 37].

\section{RESULTS AND DISCUSSION}

\section{Result of pre-compression parameters}

The powder bed was evaluated for the rheological properties like Bulk density, Tapped density, Angle of repose using standard pharmacopoeial techniques and from the results, Carr's index,
Hausner's ratio were computed. Results of triplicate readings were averaged.

\section{Bulk density}

The apparent bulk densities for all formulated batches were found to be in between $0.543 \pm 0.023 \mathrm{gm} / \mathrm{ml}$ and $0.586 \pm 0.028 \mathrm{gm} / \mathrm{ml} \mathrm{Bulk}$ densities were found in acceptable limits, which indicating that the packing properties required during compression are adequate in all formulations.

\section{Tapped density}

The values of tapped density were found to be in between $0.586 \pm 0.028 \mathrm{gm} / \mathrm{ml}$ and $0.626 \pm 0.011 \mathrm{gm} / \mathrm{ml}$ Tap densities were found in acceptable limit, which indicating that the packing properties required during compression are adequate in all formulations.

\section{Percentage carr's index}

The values of percentage Carr's index range from $6.063 \pm 2.602 \%$ to $8.246 \pm 0.323 \%$, indicating that the blends have excellent compressibility.

\section{Hausner's ratio}

Flow property was also insured by measuring Hausner's ratio. The values were found to be in between $1.052 \pm 0.039$ to $1.1056 \pm 0.037$ which indicates excellent flowing property.

\section{The angle of repose}

The angle of repose of all formulated batches was found to be between $21.443^{\circ} \pm 0.965$ and $23.636^{\circ} \pm 4.602$, which implies good free-flowing nature of blends from hopper to die cavity.

Table 2: Result of pre-compression parameters

\begin{tabular}{|c|c|c|c|c|c|c|c|c|c|c|}
\hline S. No. & Parameter & F1 & F2 & F3 & F4 & F5 & F6 & F7 & F8 & F9 \\
\hline 1. & $\begin{array}{l}\text { Bulk Density } \\
\pm S D(n=3)\end{array}$ & $0.58 \pm 0.01$ & $0.54 \pm 0.192$ & $0.55 \pm 0.01$ & $0.54 \pm 0.04$ & $0.56 \pm 0.089$ & $0.54 \pm 0.04$ & $0.57 \pm 0.01$ & $0.58 \pm 0.186$ & $0.54 \pm 0.097$ \\
\hline 2. & $\begin{array}{l}\text { Bulk Density } \\
\pm S D(n=3)\end{array}$ & $0.62 \pm 0.05$ & $0.58 \pm 0.189$ & $0.60 \pm 0.04$ & $0.58 \pm 0.08$ & $0.60 \pm 0.05$ & $0.59 \pm 0.03$ & $0.61 \pm 0.01$ & $0.63 \pm 0.06$ & $0.58 \pm 0.05$ \\
\hline 3. & $\begin{array}{l}\text { Bulk Density } \\
\pm S D(n=3)\end{array}$ & $6.41 \pm 0.04$ & $7.5 \pm 0.026$ & $8.246 \pm 0.05$ & $7.36 \pm 0.04$ & $7.17 \pm 0.06$ & $9.27 \pm 0.01$ & $6.06 \pm 0.05$ & $7.34 \pm 0.18$ & $7.36 \pm 0.03$ \\
\hline 4. & $\begin{array}{l}\text { Bulk Density } \\
\pm S D(n=3)\end{array}$ & $1.065 \pm 0.168$ & $1.084 \pm 0.094$ & $1.080 \pm 0.01$ & $1.079 \pm 0.018$ & $1.076 \pm 0.04$ & $1.105 \pm 0.01$ & $1.061 \pm 0.05$ & $1.076 \pm 0.02$ & $1.073 \pm 0.01$ \\
\hline 5. & $\begin{array}{l}\text { Bulk Density } \\
\pm \text { SD }(n=3)\end{array}$ & $23.63 \pm 0.02$ & $21.63 \pm 0.04$ & $22.44 \pm 0.01$ & $21.63 \pm 0.06$ & $21.66 \pm 0.07$ & $22.58 \pm 0.195$ & $22.63 \pm 0.08$ & $23.15 \pm 0.01$ & $23.16 \pm 0.06$ \\
\hline
\end{tabular}

mean $\pm S D, n=3$

\section{Result of post-compression parameters}

The mean thicknesses of all the formulations, F1 to F9 were found to be in the range of. $2.02 \pm 0.13$ to $2.313 \pm 0.45 \mathrm{~mm}$ and the tablet mean diameter of all formulations was found to be in the range of $6.01 \pm 0.01$ to $6.09 \pm 0.06 \mathrm{~mm}$. This indicated that the tablet production is consistent and reproducible. The hardness was found to be between the range of $2.24 \pm 0.01$ to $2.67 \pm 0.005 \mathrm{~kg} / \mathrm{cm}^{2}$, indicating that tablets have good mechanical strength.

All the batches of all the formulation tablets were found to pass the weight variation test as the friability is less than $1 \% \mathrm{w} / \mathrm{w}$. The formulations F1, F2, and F3 were prepared with $5 \mathrm{mg}$ of SSG and $20 \mathrm{mg}$,
$30 \mathrm{mg}$, and $40 \mathrm{mg}$ Ludiflash, respectively. F1, F2, and F3 showed disintegration times of 59.6, 51and 44 sec respectively and wetting times of 56.08, 50.74, and 43.68 sec respectively. The formulations F4, F5, and F6 were prepared with $10 \mathrm{mg}$ of SSG and $20 \mathrm{mg}, 30 \mathrm{mg}$, and $40 \mathrm{mg}$ Ludiflash, respectively. F4, F5, and F6 showed disintegration times of $46.5,45.7$, and $41.25 \mathrm{sec}$ respectively, and wetting times of $45.47,44.32$, $37.32 \mathrm{sec}$, respectively. The formulations F7, F8, and F9 were prepared $15 \mathrm{mg}$ of SSG and $20 \mathrm{mg}, 30 \mathrm{mg}$, and $40 \mathrm{mg}$ Ludiflash, respectively. F7, F8, and F9 showed disintegration times of 40.5,37 and 29.75 sec. Respectively and wetting times of 40.92, 29.61, and $27.89 \mathrm{sec}$ respectively. The results suggest that as the content of Ludiflash is increasing the disintegration time and wetting time of tablets decrease.

Table 3: Result of post-compression parameters

\begin{tabular}{|c|c|c|c|c|c|c|c|}
\hline S. No. & $\begin{array}{l}\text { Batch } \\
\text { code }\end{array}$ & $\begin{array}{l}\text { Thickness } \\
(\mathrm{mm}) \pm S D(n=3)\end{array}$ & $\begin{array}{l}\text { Diameter } \\
(\mathrm{mm}) \pm S D(n=3)\end{array}$ & $\begin{array}{l}\text { Hardness } \\
\left(\mathrm{kg} / \mathrm{cm}^{2}\right) \pm S D(n=3)\end{array}$ & $\begin{array}{l}\text { Weight } \\
\text { variation } \pm S D(n=3)\end{array}$ & $\begin{array}{l}\text { Friability } \\
\% \pm S D(n=3)\end{array}$ & $\begin{array}{l}\text { Disintegration time } \\
(\mathrm{sec}) \pm \mathrm{SD}(\mathrm{n}=3)\end{array}$ \\
\hline 1. & F1 & $2.18 \pm 0.001$ & $6.053 \pm 0.066$ & $2.24 \pm 0.01$ & $74.933 \pm 0.125$ & $0.778 \pm 0.102$ & $59.56 \pm 0.087$ \\
\hline 2. & $\mathrm{~F} 2$ & $2.096 \pm 0.098$ & $6.052 \pm 0.055$ & $2.675 \pm 0.005$ & $75.283 \pm 1.113$ & $0.444 \pm 0.280$ & $51 \pm 0.092$ \\
\hline 3. & F3 & $2.050 \pm 0.120$ & $6.056 \pm 0.055$ & $2.57 \pm 0.02$ & $75.766 \pm 0.577$ & $0.416 \pm 0.295$ & $44 \pm 0.148$ \\
\hline 4. & F4 & $2.313 \pm 0.452$ & $6.01 \pm 0.011$ & $2.463 \pm 0.005$ & $75.8 \pm 0.507$ & $0.770 \pm 0.169$ & $48 \pm 0.092$ \\
\hline 5. & F5 & $2.09 \pm 0.084$ & $6.05 \pm 0.060$ & $2.523 \pm 0.005$ & $73.4 \pm 1.732$ & $0.636 \pm 0.048$ & $45.7 \pm 0.01$ \\
\hline 6. & F6 & $2.04 \pm 0.113$ & $6.053 \pm 0.064$ & $2.39 \pm 0.01$ & $75.75 \pm 0.409$ & $0.572 \pm 0.268$ & $46.5 \pm 0.06$ \\
\hline 7. & F7 & $2.02 \pm 0.13$ & $6.081 \pm 0.111$ & $2.343 \pm 0.015$ & $74.65 \pm 1.125$ & $0.402 \pm 0.244$ & $40.5 \pm 0.102$ \\
\hline 8. & F8 & $2.262 \pm 0.620$ & $6.059 \pm 0.070$ & $2.523 \pm 0.015$ & $75.3167 \pm 1.284$ & $0.772 \pm 0.154$ & $37 \pm 0.068$ \\
\hline 9. & F9 & $2.15 \pm 0.049$ & $6.097 \pm 0.066$ & $2.33 \pm 0.01$ & $74.616 \pm 0.288$ & $0.536 \pm 0.068$ & $29.75 \pm 0.048$ \\
\hline
\end{tabular}

Mean \pm SD, $n=3$ 


\section{Result of in vitro drug release data of formulation F1-F3}

\section{In vitro drug release data of formulation $\mathrm{F} 1(\mathrm{n}=3)$}

The F1 formulation, containing $5 \mathrm{mg}$ of SSG and $20 \mathrm{mg}$ of Ludiflash was found to release nearly $17 \%$ of the drug into dissolution fluid within the first $10 \mathrm{~min}$. The drug release into dissolution media continues gradually and in $75 \mathrm{~min}$ if could release $84 \%$ of the drug. The raw data obtained were subjected to regression analysis and cum $\%$ of drug release was plotted against time $[38,39]$.

\section{In vitro drug release data of formulation $\mathrm{F} 2(\mathrm{n}=3)$}

The F2 formulation, containing $5 \mathrm{mg}$ of SSG and $30 \mathrm{mg}$ of Ludiflash was found to release nearly $18.23 \%$ of the drug into dissolution fluid within the first $10 \mathrm{~min}$. The drug release into dissolution media continues gradually and in $75 \mathrm{~min}$ if could release $95.85 \%$ of the drug. The raw data obtained were subjected to regression analysis and cum $\%$ of drug release was plotted against time $[38,39]$.

\section{In vitro drug release data of formulation $\mathrm{F} 3(\mathrm{n}=3)$}

The F3 formulation, containing $5 \mathrm{mg}$ of SSG and $40 \mathrm{mg}$ of Ludiflash was found to release nearly $22.90 \%$ of the drug into dissolution fluid within the first $10 \mathrm{~min}$. The drug release into dissolution media continues gradually and in $60 \mathrm{~min}$ it could release $84.58 \%$ of the drug. The raw data obtained were subjected to regression analysis and cum $\%$ of drug release was plotted against time [38, 39].

In the above discussion of F1, F2 and F3 containing $5 \mathrm{mg}$ of SSG and varying amounts of Ludifash $20 \mathrm{mg}, 30 \mathrm{mg}$, and $40 \mathrm{mg}$, respectively, the release rate constant was found to increase in the following order $\mathrm{F} 3>\mathrm{F} 2>\mathrm{F} 1$ and the disintegration time was found to be $\mathrm{F} 3<\mathrm{F} 2<\mathrm{F} 3$.

Table 4: Result of in vitro drug release data of formulation F1-F3

\begin{tabular}{|c|c|c|c|c|c|c|c|}
\hline \multirow{2}{*}{$\begin{array}{l}\text { S. } \\
\text { No. }\end{array}$} & \multirow{2}{*}{$\begin{array}{l}\text { Time } \\
\text { (min) }\end{array}$} & \multicolumn{2}{|l|}{ F1 } & \multicolumn{2}{|l|}{ F2 } & \multicolumn{2}{|l|}{ F3 } \\
\hline & & $\begin{array}{l}\text { Cumulative drug } \\
\text { release (CDR) } \pm S D \\
(n=3)\end{array}$ & $\begin{array}{l}\text { Cumulative drug } \\
\text { release \% (\%CDR) } \\
\pm \text { SD (n=3) }\end{array}$ & $\begin{array}{l}\text { Cumulative drug } \\
\text { release (CDR) } \\
\pm S D(n=3) \\
\pm\end{array}$ & $\begin{array}{l}\text { Cumulative drug } \\
\text { release \% (\%CDR) } \\
\pm \text { SD (n=3) }\end{array}$ & $\begin{array}{l}\text { Cumulative drug } \\
\text { release }(C D R) \pm S D \\
(n=3)\end{array}$ & $\begin{array}{l}\text { Gumulative drug } \\
\text { release } \%(\% \\
\text { CDR }) \pm S D(n=3)\end{array}$ \\
\hline 1. & 0 & 0 & 0 & 0 & 0 & 0 & 0 \\
\hline 2. & 1 & $0.100452565 \pm 0.049$ & $2.5142684 \pm 0.164$ & $0.095508 \pm 0.079$ & $2.3945213 \pm 0.047$ & $0.114784 \pm 0.094$ & $2.8985802 \pm 0.083$ \\
\hline 3. & 3 & $0.256637613 \pm 0.047$ & $6.4234879 \pm 0.068$ & $0.225545 \pm 0.049$ & $5.6547348 \pm 0.069$ & $0.323433 \pm 0.045$ & $8.1674946 \pm 0.026$ \\
\hline 4. & 5 & $0.455397251 \pm 0.063$ & $11.398324 \pm 0.124$ & $0.40067 \pm 0.84$ & $10.045391 \pm 0.056$ & $0.598961 \pm 0.174$ & $15.125272 \pm 0.074$ \\
\hline 5. & 10 & $0.696563862 \pm 0.047$ & $17.434582 \pm 0.162$ & $0.727154 \pm 0.048$ & $18.230805 \pm 0.092$ & $0.907174 \pm 0.19$ & $22.908434 \pm 0.046$ \\
\hline 6. & 15 & $1.038467985 \pm 0.074$ & $25.992241 \pm 0.082$ & $1.220583 \pm 0.042$ & $30.601798 \pm 0.0956$ & $1.467147 \pm 0.024$ & $37.049171 \pm 0.076$ \\
\hline 7. & 30 & $1.500553134 \pm 0.086$ & $37.557959 \pm 0.163$ & $1.813912 \pm 0.086$ & $45.477415 \pm 0.092$ & $1.9765 \pm 0.083$ & $49.91162 \pm 0.186$ \\
\hline 8. & 45 & $2.049463627 \pm 0.045$ & $51.296864 \pm 0.164$ & $2.48468 \pm 0.194$ & $62.294536 \pm 0.179$ & $2.66403 \pm 0.179$ & $67.273472 \pm 0.178$ \\
\hline 9. & 60 & $2.709001006 \pm 0.049$ & $67.804696 \pm 0.086$ & $3.153939 \pm 0.167$ & $79.073835 \pm 0.092$ & $3.349547 \pm 0.086$ & $84.584531 \pm 0.187$ \\
\hline 10. & 75 & $3.385300034 \pm 0.92$ & $84.732061 \pm 0.176$ & $3.823198 \pm 0.047$ & $95.853135 \pm 0.178$ & $4.035568 \pm 0.142$ & $101.90829 \pm 0.168$ \\
\hline
\end{tabular}

${ }^{*}$ Data are expressed as mean \pm SD $(n=3)$

\section{Comparative in vitro drug release data of formulation F1-F3}

The comparative study of dissolution profile of formulations F1, F2, and F3 was prepared with $5 \mathrm{mg}$ of sodium starch glycolate and 20 $\mathrm{mg}, 30 \mathrm{mg}$, and $40 \mathrm{mg}$ Ludiflash, respectively. Each of the tablets in all the formulations contains $5 \mathrm{mg}$ of Tofacitinib citrate. The percentage release of drugs from F1, F2, and F3 were found to be $84.7320 \%, 95.8531 \%$, and $101.9082 \%$ in $75 \mathrm{~min}$. Study respectively. The slope values of release data suggest that as the amount of Ludiflash increased rate of release of the drug gradually increases. The order of the above formulation was obtained in the following manner $\mathrm{F} 1<\mathrm{F} 2<\mathrm{F} 3$.

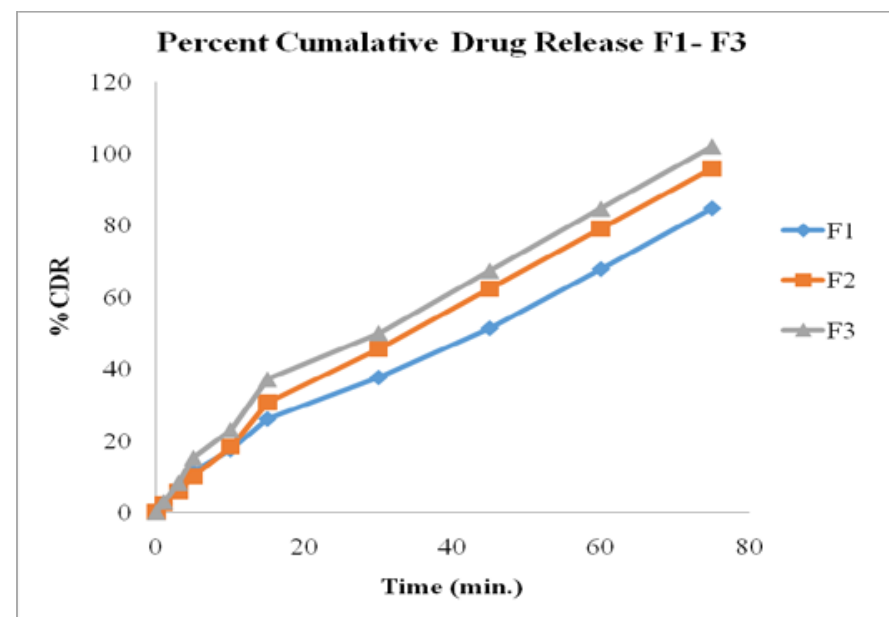

Fig. 1: Comparative in vitro drug release profile of formulations F1-F3, in vitro drug release data of formulation F1-F3 (data represents mean $\pm S D, n=3$ )

\section{Result of in vitro drug release data of formulation F4-F6}

\section{In vitro drug release data of formulation $\mathrm{F} 4$}

The F4 formulation, containing $10 \mathrm{mg}$ of SSG and $20 \mathrm{mg}$ of Ludiflash was found to release nearly $21.26 \%$ of the drug into dissolution fluid within the first $10 \mathrm{~min}$. The drug release into dissolution media continues gradually and in $75 \mathrm{~min}$ it could release $96.71 \%$ of the drug. The raw data obtained were subjected to regression analysis and cum $\%$ of drug release was plotted against time [38, 39].

\section{In vitro drug release data of formulation $F 5$}

The F5 formulation, containing $10 \mathrm{mg}$ of SSG and $30 \mathrm{mg}$ of Ludiflash was found to release nearly $23.76 \%$ of the drug into dissolution fluid within the first $10 \mathrm{~min}$. The drug release into dissolution media 
continues gradually and in $60 \mathrm{~min}$ it could release $83.51 \%$ of the drug. The raw data obtained were subjected to regression analysis and cum $\%$ of drug release was plotted against time [38,39].

\section{In vitro drug release data of formulation $\mathrm{F} 6$}

The F6 formulation, containing $10 \mathrm{mg}$ of SSG and $40 \mathrm{mg}$ of Ludiflash was found to release nearly $25.17 \%$ of the drug into dissolution fluid within the first $10 \mathrm{~min}$. The drug release into dissolution media continues gradually and in $60 \mathrm{~min}$ it could release $89.22 \%$ of the drug. The raw data obtained were subjected to regression analysis and cum $\%$ of drug release was plotted against time [38, 39].

In the above discussion of F4, F5 and F6 containing $10 \mathrm{mg}$ of SSG and varying amounts of Ludifash $20 \mathrm{mg}, 30 \mathrm{mgand} 40 \mathrm{mg}$, respectively, the release rate constant was found to increase in the following order $\mathrm{F} 6>\mathrm{F} 5>\mathrm{F} 4$, and the disintegration time was found to be $\mathrm{F} 6<\mathrm{F} 5<\mathrm{F} 4$.

Table 5: In vitro drug release data of formulation F4-F6

\begin{tabular}{|c|c|c|c|c|c|c|c|}
\hline \multirow{2}{*}{$\begin{array}{l}\text { S. } \\
\text { No. }\end{array}$} & \multirow{2}{*}{$\begin{array}{l}\text { Time } \\
\text { (min) }\end{array}$} & \multicolumn{2}{|l|}{ F4 } & \multicolumn{2}{|l|}{ F5 } & \multicolumn{2}{|l|}{ F6 } \\
\hline & & $\begin{array}{l}\text { Cumulative drug } \\
\text { release } \\
(C D R) \pm S D(n=3)\end{array}$ & $\begin{array}{l}\text { Cumulative drug } \\
\text { release \% } \\
(\% \text { CDR) } \pm \text { SD } \\
(n=3)\end{array}$ & $\begin{array}{l}\text { Cumulative drug } \\
\text { release } \\
(\text { CDR } \pm \operatorname{SD}(n=3)\end{array}$ & $\begin{array}{l}\text { Cumulative drug } \\
\text { release } \% \\
(\% C D R) \pm S D \\
(n=3)\end{array}$ & $\begin{array}{l}\text { Cumulative drug } \\
\text { release (CDR) } \\
\pm S D(n=3)\end{array}$ & $\begin{array}{l}\text { Cumulative drug } \\
\text { release } \% \\
(\% \text { CDR } \pm \text { SD } \\
(n=3)\end{array}$ \\
\hline 1. & 0 & 0 & 0 & 0 & 0 & 0 & 0 \\
\hline 2. & 1 & $0.106403 \pm 0.094$ & $2.6767364 \pm 0.054$ & $0.140764 \pm 0.069$ & $3.5387483 \pm 0.086$ & $0.147637 \pm 0.093$ & $3.6922075 \pm 0.073$ \\
\hline 3. & 3 & $0.263091 \pm 0.079$ & $6.6184712 \pm 0.068$ & $0.33768 \pm 0.056$ & $8.4891193 \pm 0.094$ & $0.338686 \pm 0.172$ & $8.4701111 \pm \pm 0.095$ \\
\hline 4. & 5 & $0.537278 \pm 0.095$ & $13.516085 \pm 0.082$ & $0.6117 \pm 0.163$ & $15.377838 \pm 0.186$ & $0.604995 \pm 0.18$ & $15.13017 \pm 0.08$ \\
\hline 5. & 10 & $0.845491 \pm 0.087$ & $21.269682 \pm 0.075$ & $0.945391 \pm 0.195$ & $23.766669 \pm 0.084$ & $1.006571 \pm 0.064$ & $25.173075 \pm 0.085$ \\
\hline 6. & 15 & $1.229635 \pm 0.034$ & $30.933425 \pm 0.186$ & $1.373952 \pm 0.026$ & $34.54051 \pm 0.162$ & $1.524472 \pm 0.069$ & $38.125144 \pm 0.19$ \\
\hline 7. & 30 & $1.823802 \pm 0.017$ & $45.880646 \pm 0.854$ & $1.96175 \pm 0.048$ & $49.31746 \pm 0.054$ & $2.209152 \pm 0.83$ & $55.248133 \pm 0.029$ \\
\hline 8. & 45 & $2.474958 \pm 0.025$ & $62.26153 \pm 0.094$ & $2.645592 \pm 0.182$ & $66.508917 \pm 0.059$ & $2.884613 \pm 0.067$ & $72.140569 \pm 0.095$ \\
\hline 9. & 60 & $3.159806 \pm 0.085$ & $79.489964 \pm 0.169$ & $3.321891 \pm 0.059$ & $83.510753 \pm 0.078$ & $3.567784 \pm 0.054$ & $89.225832 \pm 0.059$ \\
\hline 10. & 75 & $3.844653 \pm 0.074$ & $96.718398 \pm 0.189$ & $3.99886 \pm 0.087$ & $100.52944 \pm 0.534$ & $4.251626 \pm 0.029$ & $106.32786 \pm 0.068$ \\
\hline
\end{tabular}

*Data are expressed as mean \pm SD $(n=3)$

\section{Comparative in vitro drug release data of formulation F4-F6}

The comparative study of dissolution profile of formulations F4, F5, and F6 was prepared with $10 \mathrm{mg}$ of sodium starch glycolate and 20 $\mathrm{mg}, 30 \mathrm{mg}$, and $40 \mathrm{mg}$ Ludiflash, respectively. Each of the tablets in all the formulations contains $5 \mathrm{mg}$ of Tofacitinib Citrate. The basic in vitro data obtained were tabulated (table 9, 10, and 11); the percentage release of drugs from F4, F5, and F6 were found to be $96.71 \%, 100 \%$, and $106 \%$ in 75 min. Study respectively. The slope values of release data suggest that as the amount of Ludiflash increased rate of release of the drug gradually increases. The order of the above formulation was obtained in the following manner $\mathrm{F} 4<\mathrm{F} 5<\mathrm{F} 6$.

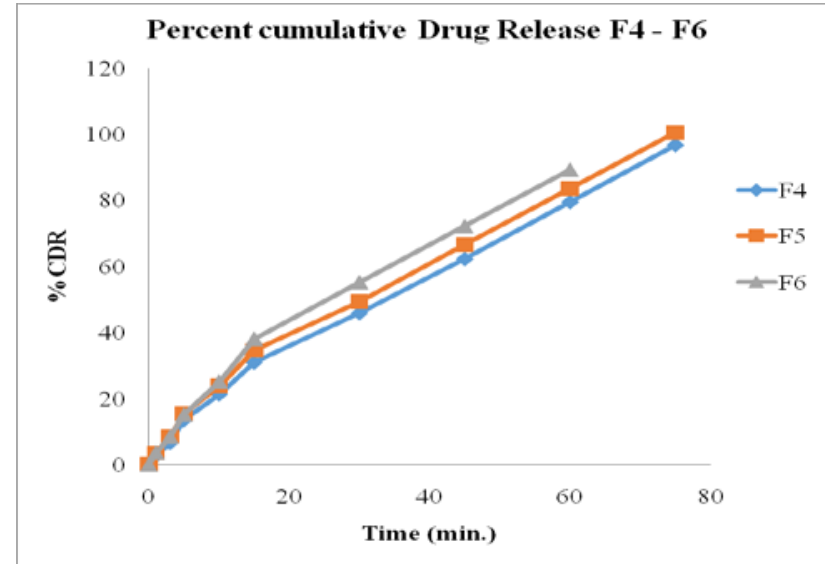

Fig. 2: Comparative in vitro drug release profile of formulations F4-F6, In vitro drug release data of formulation F4-F6 (data represents mean $\pm S D, n=3$ )

\section{Result of in vitro drug release data of formulation F7-F9}

In vitro drug release data of formulation $F 7(n=3)$

The F7 formulation, containing $15 \mathrm{mg}$ of SSG and $20 \mathrm{mg}$ of Ludiflash was found to release nearly $26.70 \%$ of the drug into dissolution fluid within the first $10 \mathrm{~min}$. The drug release into dissolution media continues gradually and in $60 \mathrm{~min}$ it could release $91.87 \%$ of the drug. The raw data obtained were subjected to regression analysis and cum $\%$ of drug release was plotted against time $[38,39]$.

\section{In vitro drug release data of formulation $\mathrm{F} 8$}

The F8 formulation, containing $15 \mathrm{mg}$ of SSG and $30 \mathrm{mg}$ of Ludiflash was found to release nearly $39.039 \%$ of the drug into dissolution fluid within the first $10 \mathrm{~min}$. The drug release into dissolution media continues gradually and in $60 \mathrm{~min}$ it could release $99.84 \%$ of the drug. The raw data obtained were subjected to regression analysis and cum $\%$ of drug release was plotted against time [38, 39].

\section{In vitro drug release data of formulation F9}

The F9 formulation, containing $15 \mathrm{mg}$ of SSG and $40 \mathrm{mg}$ of Ludiflash was found to release nearly $39.573 \%$ of the drug into dissolution fluid within the first $10 \mathrm{~min}$. The drug release into dissolution media continues gradually and in 30 min it could release $100 \%$ of the drug. The raw data obtained were subjected to regression analysis and cum $\%$ of drug release was plotted against time $[38,39]$.

In the above discussion of F7, F8 andF9, containing $15 \mathrm{mg}$ of SSG and varying amounts of Ludifash $20 \mathrm{mg}, 30 \mathrm{mg}$ and $40 \mathrm{mg}$, respectively, the release rate constant was found to increase in the following order $\mathrm{F} 9>\mathrm{F} 8>\mathrm{F} 7$, and the disintegration time was found to be $\mathrm{F} 9<\mathrm{F} 8<\mathrm{F} 7$. 
Table 6: In vitro drug release data of formulation F7-F9

\begin{tabular}{|c|c|c|c|c|c|c|c|}
\hline \multirow{2}{*}{$\begin{array}{l}\text { S. } \\
\text { No. }\end{array}$} & \multirow{2}{*}{$\begin{array}{l}\text { Time } \\
\text { (min) }\end{array}$} & \multicolumn{2}{|l|}{ F7 } & \multicolumn{2}{|l|}{ F8 } & \multicolumn{2}{|l|}{ F9 } \\
\hline & & $\begin{array}{l}\text { Cumulative } \\
\text { drug release } \\
(\mathrm{CDR}) \pm \mathrm{SD} \\
(\mathrm{n}=3)\end{array}$ & $\begin{array}{l}\text { Cumulative drug } \\
\text { release \% } \\
(\% C D R) \pm S D \\
(n=3)\end{array}$ & $\begin{array}{l}\text { Cumulative drug } \\
\text { release (CDR) } \pm \\
\text { SD }(n=3)\end{array}$ & $\begin{array}{l}\text { Cumulative drug } \\
\text { release } \% \\
(\% C D R) \pm S D(n=3)\end{array}$ & $\begin{array}{l}\text { Cumulative drug } \\
\text { release } \\
(C D R) \pm S D(n=3)\end{array}$ & $\begin{array}{l}\text { Cumulative drug } \\
\text { release \% } \\
(\% C D R) \pm S D \\
(n=3)\end{array}$ \\
\hline 1 & 0 & 0 & 0 & 0 & 0 & 0 & 0 \\
\hline 2. & 1 & $0.149313 \pm 0.046$ & $3.7341263 \pm 0.084$ & $0.1556822 \pm 0.074$ & $3.916434785 \pm 0.028$ & $0.17378478 \pm 0.018$ & $4.34614066 \pm 0.124$ \\
\hline 3. & 3 & $0.3412 \pm 0.0845$ & $8.5329899 \pm 0.047$ & $0.63419376 \pm 0.089$ & $15.95415875 \pm 0.049$ & $0.834495474 \pm 0.092$ & $20.8696912 \pm 0.189$ \\
\hline 4. & 5 & $0.632987 \pm 0.092$ & $15.830214 \pm 0.82$ & $1.14958096 \pm 0.074$ & $28.91954816 \pm 0.189$ & $1.582366745 \pm 0.047$ & $39.5730191 \pm 0.029$ \\
\hline 5. & 10 & $1.067751 \pm 0.079$ & $26.703111 \pm 0.195$ & $1.68457928 \pm 0.039$ & $42.3782869 \pm 0.058$ & $2.35822997 \pm 0.062$ & $58.9763909 \pm 0.068$ \\
\hline 6. & 15 & $1.638116 \pm 0.058$ & $40.967238 \pm 0.049$ & $2.26516929 \pm 0.082$ & $56.98395745 \pm 0.075$ & $3.174824003 \pm 0.054$ & $79.3983895 \pm 0.048$ \\
\hline 7. & 30 & $2.3176 \pm 0.045$ & $57.960279 \pm 0.192$ & $2.86570567 \pm 0.09$ & $72.09141067 \pm 0.052$ & $4.006838753 \pm 0.059$ & $100.206040 \pm 0.049$ \\
\hline 8. & 45 & $2.9969 \pm 0.0783$ & $74.949129 \pm 0.078$ & $3.48166276 \pm 0.039$ & $87.5867967 \pm 0.054$ & - & - \\
\hline 9. & 60 & $3.67355 \pm 0.069$ & $91.870908 \pm 0.029$ & $3.99537378 \pm 0.086$ & $100.5100195 \pm 0.058$ & - & - \\
\hline
\end{tabular}

${ }^{*}$ Data are expressed as mean \pm SD $(n=3)$

\section{Comparative in vitro drug release data of formulation F7-F9}

The comparative study of dissolution profile of formulations F7, F8, and F9 was prepared with $15 \mathrm{mg}$ of sodium starch glycolate and 20 $\mathrm{mg}, 30 \mathrm{mg}$, and $40 \mathrm{mg}$ Ludiflash, respectively. Each of the tablets in all the formulations contain $5 \mathrm{mg}$ of Tofacitinib Citrate. The percentage release of drugs from F7, F8, and F9 were found to be $91.87 \%, 99.84 \%$, and $100 \%$ in 60, 60, and $30 \mathrm{~min}$. Study respectively. The slope values of release data suggest that as the amount of Ludiflash increased rate of release of the drug gradually increased. The order of the above formulation was obtained in the following manner $\mathrm{F} 4<\mathrm{F} 5<\mathrm{F} 6$.

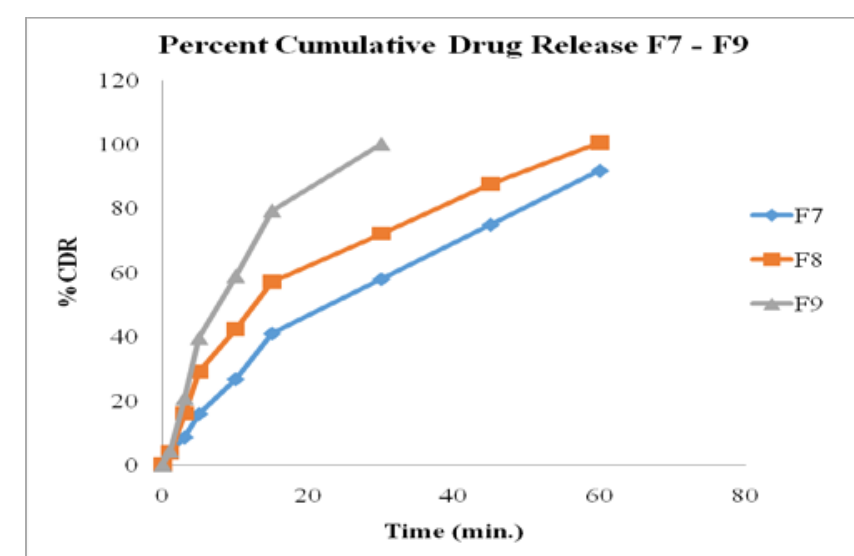

Fig. 3: Comparative in vitro drug release profile of formulations F7-F9, In vitro drug release data of formulation F7-F9 (data represents mean $\pm S D, n=3$ )

Result of stability studies of F9 formulation: stability studies at $40{ }^{\circ} \mathrm{C} / 75 \% \mathrm{RH}$

The stability of Tofacitinib citrate in the fast dissolving tablets was assessed according to ICH guidelines. Arrangements were made inside a stability chamber to induce stress of temperature and humidity simultaneously and uniformly and all the tablets were kept for study [40]. A temperature of $40^{\circ} \mathrm{C}$ and relative humidity of $75 \% \mathrm{RH}$ were selected, and the $\mathrm{F} 9$ formulation was selected as a model dosage form. Nearly 50 tablets of F9 were placed inside the stability chamber so that each tablet is separated and was exposed to $40{ }^{\circ} \mathrm{C} / 75 \% \mathrm{RH}$. At the end of $24 \mathrm{~h}, 30 \mathrm{~d}, 60$ days, and $90 \mathrm{~d}, 3$ tablets were removed randomly and were subjected to dissolution. The tablets were inspected surely for any chamber [41]. The dissolution profiles were obtained and the results of these formulations were compared with the dissolution profile of the tablet which was no exposure to stress [42]. The profiles of the formulation F9 were seen to remain similar, indicated by slope, visual inspection showed that there was no apparent effect of temperature/humidity a color, odor, etc. which given in table 7.

Table 7: Result of stability studies of F9 formulation

\begin{tabular}{|c|c|c|c|c|c|}
\hline \multirow[t]{2}{*}{ S. No. } & \multirow{2}{*}{$\begin{array}{l}\text { Time } \\
\text { (min) }\end{array}$} & Day (d) $1^{\text {st }}$ & Day (d) $30^{\text {th }}$ & Day (d) 60"th & Day (d) 90 \\
\hline & & $\begin{array}{l}\text { Cumulative drug release } \\
(\% C D R) \pm S D(n=3)\end{array}$ & $\begin{array}{l}\text { Cumulative drug release } \% \\
(\% C D R) \pm S D(n=3)\end{array}$ & $\begin{array}{l}\text { Cumulative drug release } \\
\%(\% C D R) \pm S D(n=3)\end{array}$ & $\begin{array}{l}\text { Cumulative drug release } \\
\%(\% C D R) \pm S D(n=3)\end{array}$ \\
\hline 1. & 0 & 0 & 0 & 0 & 0 \\
\hline 2. & 1 & $4.34614 \pm 0.04$ & $4.119779 \pm 0.127$ & $4.351716 \pm 0.048$ & $4.348949 \pm 0.097$ \\
\hline 3. & 3 & $20.84035 \pm 0.08$ & $20.52177 \pm 0.076$ & $20.72436 \pm 0.08$ & $20.89903 \pm 0.094$ \\
\hline 4. & 5 & $39.5311 \pm 0.092$ & $39.11191 \pm 0.084$ & $39.22228 \pm 0.192$ & $40.02293 \pm 0.079$ \\
\hline 5. & 10 & $58.96243 \pm 0.089$ & $58.54463 \pm 0.057$ & $58.81429 \pm 0.054$ & $59.27121 \pm 0.068$ \\
\hline 6. & 15 & $79.37605 \pm 0.0492$ & $78.67181 \pm 0.082$ & $79.19437 \pm 0.073$ & $79.68063 \pm 0.082$ \\
\hline 7. & 30 & $100.1697 \pm 0.059$ & $99.506 \pm 0.067$ & $99.99502 \pm 0.14$ & $100.3597 \pm 0.095$ \\
\hline
\end{tabular}

Standard Deviation (SD) n=3, from the stability study data, it was clear that drug was stable in the optimized formulation for the study period. 
Therefore it was concluded that the drug Tofacitinib Citrate formulation can retain its original potency for at least $2 \mathrm{y}$. The ICH guidelines require 6 mo of study, but because of time constraint, the results of only 3 mo study has been reported; the remaining studies would be reported elsewhere at a later time.

\section{CONCLUSION}

The concept of formulating Mouth Dissolving Tablets of Tofacitinib Citrate using super disintegrants offers a suitable and practical of faster disintegration and dissolution characteristics. Tofacitinib Citrate was characterized by studying its absorbance, melting point, Partition coefficient and solubility in water, and various solvents and FTIR spectroscopy. The present investigation successfully formulated mouth dissolving tablets of Tofacitinib citrate with an improved drug release profile. It is concluded that the amount of Superdisintegrants decreases the disintegration time of tablets, decreases wetting time, increases the cumulative \% drug release causes better absorption. The future looks bright for patients as many new drugs are being developed and now combinations of JAK inhibitors with other targeted agents are being studied in the clinic. These advances are expected to lead to further significant progress in improving patient outcomes and quality of life.

\section{FUNDING}

Nil

\section{AUTHORS CONTRIBUTIONS}

All authors have contributed equally.

\section{CONFLICT OF INTERESTS}

The authors declared that the No conflict of interest for the given Article.

\section{REFERENCES}

1. Shyamala B, Narmada GY. Rapid dissolving tablets: A novel dosage form. Indian Pharm. 2002;13(8):9-12.

2. RM Thorat, VM Jadhav, VJ Kadam, SS Kamble, KP Salaskar. Development of HPTLC method for estimation of wedelolactone, quercetin and jatamansone in polyherbal formulation. Int J PharmTech Res Coden (USA) 2009;1(4):1079-91.

3. Avani F. Amin emerging trends in the development of orally disintegrating tablet technology pharmainfo; 2006

4. Reddy PS, Bose PSC, Saritha D, Sruthi V. Formulation and evaluation of colon targeted matrix tablet using natural tree gums. Int J Pharm Pharm Sci. 2018;10(9):92-7. doi: 10.22159/ijpps.2018v10i9.27255.

5. Meghawati R, Borse SL, Junagade MS, Jadha AG. Formulation and evaluation of mouth dissolving tablet of amlodipine besylate. Int J Appl Pharm. 2019;11(4):132-9.

6. Fleischmann R, Kremer J, Cush J, Schulze Koops H, Connell CA, Bradley JD, Gruben D, Wallenstein GV, Zwillich SH, Kanik KS, ORAL Solo Investigators. Placebo-controlled trial of tofacitinib monotherapy in rheumatoid arthritis. N Engl J Med. 2012;367(6):495-507. doi: 10.1056/NEJMoa1109071, PMID 22873530.

7. Guttman Yassky E, Silverberg JI, Nemoto O, Forman SB, Wilke A, Prescilla $\mathrm{R}$, et al. Baricitinib in adult patients with moderate-tosevere atopic dermatitis: a phase 2 parallel, double-blinded, randomized placebo-controlled multiple-dose study. J Am Acad Dermatol. 2019;80(4):913-21.e9. doi: 10.1016/j.jaad.2018.01.018, PMID 29410014.

8. https://www.rxlist.com/xeljanz-drug.html. [Last accessed on 10 Sep 2021]

9. Mukherjee A, Hazra A, Smith MK, Martin SW, Mould DR, Su C, Niezychowski W. Exposure-response characterization of tofacitinib efficacy in moderate to severe ulcerative colitis: results from a dose-ranging phase 2 trial. $\mathrm{Br} J$ Clin Pharmacol. 2018 Jul;84(6):1136-45. doi: 10.1111/bcp.13523, PMID 29377257.

10. Askari A, Nouri AK, Morrissey H, Ball PA. Janus kinase enzyme (JAK) inhibitors and Rheumatoid Arthritis: a review of the literature. Int J Curr Pharm Sci. 2019;11(6):11-4. doi: 10.22159/ijcpr.2019v11i6.36343.
11. Papp KA, Krueger JG, Feldman SR, Langley RG, Thaci D, Torii H, Tyring S, Wolk R, Gardner A, Mebus C, Tan H, Luo Y, Gupta P, Mallbris L, Tatulych S. Tofacitinib, an oral Janus kinase inhibitor, for the treatment of chronic plaque psoriasis: Longterm efficacy and safety results from 2 randomized phase-III studies and 1 open-label long-term extension study. J Am Acad Dermatol. 2016;74(5):841-50. doi: 10.1016/j.jaad.2016.01.013. PMID 26899199.

12. National Center for Biotechnology Information. Pub chem compound summary for CID 9926791. Available from: https://pubchem.tofacitinib.ncbi.nlm.nih.gov/compound/tofac itinib. [Last accessed on 31 Aug 2021]

13. Lai F, Pini E, Angioni G, Manca ML, Perricci J, Sinico C, Fadda AM. Nanocrystals as tool to improve piroxicam dissolution rate in novel orally disintegrating tablets. Eur J Pharm Biopharm. 2011;79(3):552-8. doi: 10.1016/j.ejpb.2011.07.005, PMID 21820052.

14. https://aksci.com/item_detail.php? cat $=x 7518$ [Last accessed on 17 Nov 2021].

15. https://go.drug bankdrugbank.com/drugs/DB08895 [Last accessed on 17 Nov 2021].

16. www.pharma.basf.com. [Last accessed on 17 Nov 2021]

17. Aksu B, Yegen G, Purisa S, Cevher E, Ozsoy Y. Optimisation of ondansetron orally disintegrating tablets using artificial neural networks. Trop J Pharm Res. 2014;13(9):1374-83. doi: 10.4314/tjpr.v13i9.1.

18. Pharmacotherapy Group, Faculty of Pharmacy, University of Benin. Benin City, 300001 Nigeria.

19. Devrajan PV, Gore SP. Melt-in-mouth tablets: innovative oral drug delivery system. Express Pharm Pulse. 2000;7:16-6.

20. Keny RV, Desouza C, Lourenco CF. Formulation and evaluation of rizatriptan benzoate mouth disintegrating tablets. Indian J Pharm Sci. 2010;72(1):79-85. doi: 10.4103/0250-474X.62253, PMID 20582194.

21. Thakariya NV, Ezhaya SB. Development and validation of UV spectrophotometric method for the estimation of tofacitinib citrate. Pharm Sci Monit. Apr-Jun 2017;8(2):401-8.

22. Flanagan ME, Li ZJ. Preparation of novel crystalline compound useful as inhibitors of protein kinases PCT Int. WO 2003048162 A120030612; 2003.

23. Flanagan ME, Blumenkopf TA, Brissette $\mathrm{WH}$, Brown MF, Casavant JM, Shang Poa C, Doty JL, Elliott EA, Fisher MB, Hines M, Kent C, Kudlacz EM, Lillie BM, Magnuson KS, McCurdy SP, Munchhof MJ, Perry BD, Sawyer PS, Strelevitz TJ, Subramanyam C, Sun J, Whipple DA, Changelian PS. Discovery of CP-690, 550: A potent and selective janus kinase (JAK) inhibitor for the treatment of autoimmune diseases and organ transplant rejection. J Med Chem. 2010;53(24):8468-84. doi: 10.1021/jm1004286, PMID 21105711.

24. Dnyaneshwar HR, Wale KK, Sayyed SF, Chaudhari SR. Orodispersible film dosage form: a review. World J Pharm Res. 2014;3(5):1093-111.

25. Srivastava SK, Verma R, Chandra V, Srivastava SP. Orally disintegrating tablets a dosage form that extends the market exclusivity and patent protection. World J Pharm Pharm Sci. 2014;3(7):526-46.

26. Rao MR, Sonavane V, Kulkarni S, Magar M, Zope A, Karanjkar P. Design of transdermal patch of ketoprofen by full factorial design for treatment of rheumatoid arthritis. J Drug Delivery Ther. 2019 Mar 15;9(2):197-205. doi: 10.22270/jddt.v9i2.2549.

27. Bala R, Khanna S, Pawar P. Polymers in fast disintegrating tablets: a review. Asian J Pharm Clin Res. 2012;5(2):8-14.

28. Deshpande KB, Ganesh NS. Orodispersible tablets: an overview of formulation and technology. Int J Pharm Biol Sci. 2011;2(1):726.

29. Panchal DM, Tiwari A, Srivastava P. A review on orodispersible tablets: a novel formulation for oral drug delivery system and its future prospective. Indo Am J Pharm Res. 2013;3(5):4149.

30. Bhosale NR, Kolte NS. Formulation development and evaluation of orally disintegrating tablet of chlorpheneramine maleate by sublimation technique. Int J Pharm Pharm Sci. 2019;11(9):28-36. doi: 10.22159/ijpps.2019v11i9.34387.

31. Gupta A, Mishra AK, Gupta V, Bansal P, Singh R, Singh AK. Recent trends of fast dissolving tablet: an overview of formulation technology. Int J Pharm Bio Arch. 2010;1(1):1-10. 
32. Abdul Rahoem T, Singh R, Hiremath A, Shashant Nayak NS, Kamath KS. Formulation and comparative evaluation of ondansetron hydrochloride mouth dissolving tablets in India. Int J Pharm Pharm Sci. 2019;11(4):57-64.

33. Madan J, Sharma AK, Singh R. Fast dissolving tablets of Aloe vera gel. Trop J Pharm Res. 2009;8(1):63-70. doi: 10.4314/tjpr.v8i1.14713.

34. Kaushik D, Dureja H, Saini TR. Formulation and evaluation of olanzapine mouth dissolving tablets by effervescent formulation approach. J Adv Pharm Technol Res. 2004;41(4):147-92.

35. Gaur K, Tyagi LK, Kori ML, Nema RK. Formulation and characterization of fast disintegrating tablet of aceclofenac by using sublimation method. Int J Pharm Sci Drug Res. 2011;3(1):19-22.

36. Schiermeier S, Schmidt PC. Fast dispersible ibuprofen tablets. Eur J Pharm Sci. 2002;15(3):295-305. doi: 10.1016/s09280987(02)00011-8. PMID 11923062.

37. Malke S, Shidhaye S, Kadam V. Novel melt granulation using sugars for metoclopramide hydrochloride orally disintegrating tablet. Asian J Pharm Clin Res. 2009;2(1):8-72.
38. Furtado S, Deveswaran R, Bharath S, Basavaraj BV, Abraham S, Madhavan V. Development and characterization of orodispersible tablets of famotidine containing a subliming agent. Trop J Pharm Res. 2008;7(4):1185-9. doi: 10.4314/tjpr.v7i4.14705

39. Jain CP, Naruka PS. Formulation and evaluation of fast dissolving tablets of valsartan. Int J Pharm Pharm Sci. 2009;1(1):219-26.

40. Nagendrakumar D, Raju SA, Shirsand SB, Para MS. Design of fast dissolving granisetron HCL tablets using novel coprocessed superdisintegrants. Int J Pharm Sci Rev Res. 2010;1(1):58-62.

41. Shirwalkar AA, Jacob S, Joseph A, Srinivasan KK. Novel coprocessed excipients of mannitol and microcrystalline cellulose for preparing fast dissolving tablet of glipizide. Ind J Pharm Sci. 2010:633-9.

42. Radke RS, Jadhav JK, Chajeed MR. Formulation and evaluation of orodispersible tablets of baclofen. Int J Chem Tech Res. 2009;1(3):517-21. 